Ayfer Genç Yılmaz

\title{
The national security concept and police-military relations in Turkey
}

\begin{abstract}
Szeroko definiowana koncepcja bezpieczeństwa narodowego od zawsze była w Turcji przedmiotem wielu kontrowersji. Jednak istniejące badania nie koncentrują się na niezwykle istotnym związku między niejasną definicją pojęcia a jej wpływem na stosunki policyjno-wojskowe. Aby wypełnić tę lukę, w niniejszym artykule autorka analizuje stosunki policyjno-wojskowe w Turcji w świetle historycznego rozwoju koncepcji bezpieczeństwa narodowego. W związku z tym na kartach niniejszej pracy argumentuje się, że nieprecyzyjne i wszechstronne wykorzystanie koncepcji bezpieczeństwa narodowego pozostaje niezmienione w następstwie 2000-letniego procesu cywilizacyjnego. W związku z tym, że koncepcja bezpieczeństwa narodowego nadal zachowuje swoje szerokie znaczenie, istnieje także konwergencja ról policyjno-wojskowych, lecz musi zostać przeformułowana. Jednak w tych okolicznościach policja wydaje się być wielkim beneficjentem tej zbieżności ról, gdy wojskowy reżim kurateli dobiegł końca i cywilna kontrola nad wojskiem została w pełni ustanowiona.
\end{abstract}

Słowa kluczowe: bezpieczeństwo narodowe, wojsko, policja, Turcja, konwergencja

\section{Introduction}

The concept of national security, as a strategic term, had its origins in World War II. In his early paper on national security, Wolfers ${ }^{1}$ contends that it is an ambiguous symbol and not an easy concept to be defined. Traditionally, the meaning of the concept changes in accordance with the definition of national interest under different circumstances. For example, in the 1930s, the term was in general

A. Wolfers, National security as an ambiguous symbol, „Political Science Quarterly” 1952, vol. 67, no. 4 , pp. 481-502. 
related to the welfare of the population as a consequence of the Great Depression, whereas during the Cold war years, it became related to the security of the state. Since the end of the Cold war, security has become an all-encompassing concept, and security threats have been multiplied. Yet, the significance of the national security concept persists as every country is a special place to its own citizens ${ }^{2}$.

The idealized distinction between national security and public security has been concretized with the emergence of consolidated forms of democracies. This distinction appears as a consequence of separated police and military roles. Whereas the former is occupied with public security, the latter is responsible for national security. In consolidated democracies, the domestic use of the military is accepted under restricted conditions codified in constitutions ${ }^{3}$. In countries where the security of the national state is prioritized over public security, police and military roles have always been merged. In other words, the identification of public security with state's security has implications on the relationship between the police and the military. In general, this convergence between the police and the military occurs in unconsolidated democracies of the Third world, where a clear distinction could not be established between two security institutions.

Although the literature on national security is extended, the role of the concept in determining the role distribution between two security actors, the police and the military, remains scarce. Significantly, Kincaid's study ${ }^{4}$ on El Salvador and Guatemala are inspiring in this context. The difference between national security and public security and the absorption of the latter by the former reshapes police-military relations. The impact of national security doctrines on police-military relations ${ }^{5}$ and military's domestic roles in Latin America ${ }^{6}$ are analyzed from various perspectives. In Turkey, there is a vast literature on the national security concept. For example, Özcan analyzed the historical development of the national security concept to demonstrate the instrumentalized use of the term by military authorities to increase their sphere of influence ${ }^{7}$. Çelik, in turn, contends that the

T.C. Sorensen, Rethinking national security, „Foreign Affairs” 1990, vol. 69, no. 3, p. 3.

T. Weiss, The blurring border between the police and the military: a debate without foundations, „Cooperation and Conflict” 2011, vol. 46, no. 3, pp. 396-405; D. Resteigne, P. Manigart, Boots on the streets: a policization of the armed forces as the new normal?, „Journal of Military Studies" 2019, vol. 8, no. 1, pp. 16-27.

4 A.D. Kincaid, Demilitarization and security in El Salvador and Guatemala: convergences of success and crisis, „Journal of InterAmerican Studies and World Affairs” 2000, vol. 42, no. 4, pp. 39-58.

5 D. Pion-Berlin, Latin American national security doctrines: hard and softline themes, „Armed Forces\&Society" 1989, vol. 15, no. 3, pp. 411-429.

6 A. Stepan, The new professionalism of internal warfare and military role expansion, [in:] Authoritarian Brazil origins, policies, and future, ed. A. Stepan, New Haven 1973, pp. 47-68.

7 G. Özcan, Türkiye’de milli güvenlik kavramının gelişimi, [in:] Türkiye’de ordu, devlet ve güvenlik siyaseti, eds. İ. Akça, E. Balta Paker, İstanbul 2010, pp. 307-350. 
extended and imprecise use of the concept in the hands of the military curtailed the power of the executive branch and allowed the limitation of fundamental and syndical rights ${ }^{8}$. Some scholars analyzed the national security concept based on the military's role in defining the concept, and military mechanisms determining the scope of the concept ${ }^{9}$. Other scholars examined the historical development of the concept and its impacts on rights and freedoms ${ }^{10}$. Karaosmanoğlu argued that the use of the concept provided an opportunity for military authorities to be involved in domestic issues and, in this sense, had a considerable impact on civil-military relations and human rights ${ }^{11}$. Despite the existence of abundant literature on the national security concept, the issues regarding the impact of the concept on the domestic law enforcement or policing missions of the Turkish military and on the relationship between the police and the military have been largely neglected in the literature ${ }^{12}$. In fact, the national security concept long served the military to be involved in non-military missions, including law enforcement missions of the police.

This paper aims to analyze the impact of the national security concept and its evolution over time on the role distribution among security institutions such as the police and the military in Turkey. This article is based predominantly on the analysis of primary and secondary sources such as research articles, newspapers and previous research on the subject. Additionally, legal and constitutional resources were explored in order to make an observation on the changing meaning of the national security concept in Turkish legislation. Within this context, the Turkish legislature from 1960 until 2016 were examined with a special focus on the national security concept.

The paper is organized as follows: First it examines the historical development of the concept in the context of Turkish politics. Military interventions played a crucial role in the extension of the concept. First, the 1960 coup d'Etat created a paradigmatic shift enabling the transition from national defence to national

8 S. Çelik, Osmanlidan günümüze devlet ve asker, askeri bürokrasinin sistem içindeki yeri, İstanbul 2007.

9 Ü. Cizre, Demythologizing the national security concept: the case of Turkey, „Middle East Journal” 2003, vol. 57, no. 2, pp. 213-229; A.L. Karaosmanoğlu, The evolution of the national security culture and the military in Turkey, „Journal of International Affairs” 2000, vol. 54, no. 1, pp. 199-216.

10 B. Urhan, S. Çelik, Perceptions of national security in Turkey and their impacts on the labour movement and trade union activities, „European Journal of Turkish Studies” 2010, vol. 11, https/doi,org/10.4000/ejts.4333.

11 D. Pion Berlin, The Military and Internal Security Operations in Latin America, „Revista Politica y Estrategia" 2017, vol. 130, pp. 101-123.

12 For a detailed analysis of the rise of the modern state and the establishment of a distinction between the police and the military in Turkey, see F. Ergut, Modern devlet ve polis, Osmanlidan Cumhuriyet'e toplumsal denetimin diyalektiği, İstanbul 2004. 
security. Later, through the 1980 coup d'Etat, a security state which was later consolidated throughout the 1990s, was established in Turkey. Second, during this time period, the existence of the concept reshaped the relationship between security institutions in favor of the military. Finally, the civilianization process of the 2000s is explored to demonstrate that the changing pattern of civil-military relations did not reduce the significance of the national security concept, whereas it changed the status quo and traditional role distribution among security institutions, this time in favor of the police.

\section{Historical development of the national security concept in Turkey}

National security refers to the security of the national state. Based on this, the term can be defined as ,the safeguarding of the state's sovereignty over the territory and population within its borders, and implies policies to confront any threat to that sovereignty" ${ }^{\prime 3}$. Accordingly, Dimitrijevic argues that one of the main characteristic features of the national security concept is that the state is perceived as a political community that aims to protect its integral territory and assure its political independence ${ }^{14}$. On the other hand, public security is another concept and differs radically from national security. Public security can be defined as "the maintenance of civil order along with the upholding rule of law"15.

Wolfers ${ }^{16}$ argues that the national security concept may become dangerous when it is used without any necessary specification. In this regard, sometimes, the concept is extended to include and absorb public security. In Turkey, the national security concept has been used to include both national defense and the protection of public security ${ }^{17}$. Accordingly, the use of the concept and its empowerment throughout the military tutelage regime enabled the absorption of public security into national security, eliminating the necessary difference between the two. This fusion started to occur in 1960, in the aftermath of the military coup d'Etat which signified a turning point in the sense that the Turkish military changed its doctrine and passed from national defence to national security ${ }^{18}$.

Even though in the U.S., national security as a strategic concept emerged in World War II, in Turkish legislation or political discourse, the concept had not

13 A.D. Kincaid, op.cit., p. 40.

14 B. Dimitrijevic, The concept of security in international relations, Beograd 1973.

15 D. Kincaid, op.cit.

16 A. Wolfers, op.cit.

17 G. Özcan, op.cit., pp. 307-350.

18 B. Gürpınar, Milli Güvenlik Kurulu ve dışpolitika, „Uluslararası İlişkiler” 2003, vol. 10, no. 39, p. 78. 
been used until the 1960 military intervention and the establishment of a new Constitution afterwards ${ }^{19}$. Before the military coup, Turkish legislation referred to the concept of national defence ${ }^{20}$. In other words, the military bestowed upon the duty to safeguard the homeland predominantly against external enemies. The institutional mechanism through which the government and the military collaborated was called the National Defense High Council, which was constituted in 1949. The institution had a limited role and was essentially responsible for assessing the state's defence problems and threat ${ }^{21}$. Until the restoration of civilian order through the realization of national elections on 15 X 1961 the military cadre held the necessary authority to govern the country. During the transition period from military rule to civilian government, the military established a new constitution. The so-called 1961 constitution brought a new national security concept in the place of national defence. Besides legislative reforms, on the practical level, a new institution called National Security Council (Milli Güvenlik Kurulu-MGK) was created for the execution of the national security concept. Since then, the MGK became the primary institutional mechanism of the Türk Silahlı Kuvvetleri (Turkish Armed Forces, henceforth, TSK) - led military tutelage regime.

Just before the 1971 military intervention, on 28 III 1970 through the MGK, it was declared that student protests and popular demonstrations went well beyond the borders of freedom and started to threaten public security. In turn, TSK self-declared as being capable of coping with these national security threats ${ }^{22}$. Here, national security and public security were used as synonyms. Based on this, many criticisms arose to warn public opinion against the danger of an extended definition of national security. They put forward the argument that national security should have precise limits to signify threats of external nature. The extended redefinition of the national security concept had its consequences on the institutional level. With the enlargement of the concept, the primary institutional mechanism, the MGK extended its scope of influence. Accordingly, it became the essential mechanism determining, defining, and executing national security policies.

In the aftermath of the 1971 military intervention, many constitutional amendments were put into practice to increase the military's power and autonomy. According to the newly established legislation, the MGK advised the Council

19 Özcan states that the term was used throughout the 1950s in documents prepared by the National Defense Academy. Özcan, op.cit., pp. 318-319. Yet, the use of the term by political elites and in political discourse became extensive in the 1960s, in the aftermath of the 1960 coup d'Etat.

21 Z. Sarlak, A history of the national security state in Turkey, The Doctoral Dissertation, University of Leiden, August 2020, p. 86.

22 G. Özcan, op.cit., p. 336. 
of Ministers ${ }^{23}$. Consequently, in the 1970s, on one side the definition of national security became all-encompassing and on the other side, the main institutional mechanism, the MGK, increased its role and power in internal security.

However, a total national security state in Turkey was established after the 1980 coup d'Etat ${ }^{24}$. During this period, according to military authorities, public security incidents became so severe that it started to threaten the survival of the regime in Turkey. The deteriorating public security was the primary reason behind the realization of the military coup in $1980^{25}$. In the aftermath, the fusion between the public and national security was strengthened and became the main characteristic of the military tutelage regime in Turkey. Since then, "the Council of Ministers primarily considered the decisions of the MGK"26.

The real turning point, where the tradition of military coups' creating their own laws reached its peak, was the military coup of September 12, 1980. The sphere of rights and freedoms was replaced by national security ${ }^{27}$.

Law no. 2945 in $1983^{28}$ gave a broad definition to the national security concept. The definition of the concept was further precised under the Law of the National Security Council. According to the enacted law, the concept was defined as:

the protection of the constitutional order, national integrity and all political, social, cultural and economic interests in the international scene as well as against internal and external threats ${ }^{29}$.

In this regard, national security policy contains:

the principles behind internal, external, and defence policies as specified by the Cabinet of Ministers, on the basis of views established by the National Security Council with the objective of ensuring national security and achieving national objectives $^{30}$.

23 A. Kars Kaynar, Political activism of the National Security Council after the reforms, „Armed Forces\&Society" 2017, vol. 43, no. 3, p. 526.

24 Z. Sarlak, op.cit.

25 T. Demirel, 12 eylül’e doğru ordu ve demokrasi, „Ankara SBF Üniversitesi Dergisi” 2001, vol. 56, no. 4, pp. 44-75.

26 A. Kars Kaynar, op.cit., p. 527.

27 M. Erdal, National security in the constitution, [in:] Bir zümre bir parti Türkiye'de ordu, 1st Edition, eds. A. Bayramoğlu, A. İnsel, İstanbul 2004, p. 36.

28 Law no. 2945 on the MGK and the secretariat-general of the MGK published in Official Journal, no. 18218, 11 XI 1983.

29 Milli Güvenlik Konseyince kabul edilen kanunlar, yaymlanan bildiri ve kararlar ile önemli mevzuat, ed. İ. Gülsün, C. 8., Ankara 1984, pp. 422-429.

$30 \quad$ M. Erdal, op.cit., p. 40. 
The national security concept underwent a transformation process, and its content changed and broadened in the 1990s. Sarlak ${ }^{31}$ contended that if a national security state was established in the 1980s, following the 1980 coup d'Etat; the national security state was consolidated predominantly in the 1990s. In 1992, public opinion was informed about the existence of a document entitled National Security Policy Document (Milli Güvenlik Siyaset Belgesi) which was prepared by the General Secretary of the MGK. During this period, the rising threats of political Islam and Kurdish separatism strengthened the importance of the national security concept and the TSK's role inside state borders against internal enemies ${ }^{32}$. In 1997, the military initiated a so-called postmodern military intervention ${ }^{33}$. Based on this, the General Staff declared that they passed from total war strategy to low-intensity warfare ${ }^{34}$. For example, the Ministry of National Defence's White Paper (1998) emphasized on internal threats. In other words, the priority of internal security threats over external security threats became official with such documents released by the TSK.

Besides internal factors specific to Turkey, in the 1990s, the national security concept was emphasized in relation with the international context of the post-Cold war period. In the aftermath of the Cold-war, the communist threat was eliminated. This time, the security of a nation became related to soft security concerns instead of hard security ones. Internal enemies of a nation, previously neglected during the Cold War period, regained its significance ${ }^{35}$. In this sense, The TSK's struggle against internal enemies was in accordance with the global remodeling of the security environment ${ }^{36}$. The priority of internal enemies in place of external enemies did not reduce the significance of the concept of the enemy and its importance for the state's national security ${ }^{37}$. Yet, the question of the main actor who would be responsible against this type of enemy has created many debates. Obviously, under the military tutelage regime, military authorities took the responsibility by considering the police as incapable and lacking resources. At the end of the 1990s, the concept started to be questioned as it created controversy during the democratization process. In the 2000s, Mesut Yllmaz ${ }^{38}$ opened

\section{Z. Sarlak, op.cit. \\ Ü. Cizre, op.cit., p. 214.}

3 For a detailed analysis of the 1997 postmodern coup d'Etat, see Ö. Aslan, Unarmed' we intervene, unnoticed we remain: the deviant case of 'February 28th Coup' in Turkey, „British Journal of Middle Eastern Studies" 2016, vol. 43, no. 3, pp. 360-377.

34 B. Ülman, Doksanlarda Türkiye’nin yeni güvenlik algılamaları ve 'bölücülük' [in:] En Uzun Onyıl: Türkiye’nin ulusal güvenlik ve dış politika gündeminde doksanlı yıllar, 1st Edition, eds.

G. Özcan, Ş. Kut, İstanbul 1998, pp. 101-134.

B. Ülman, op.cit.

Ü. Cizre, op.cit., p. 217.

E. Balta Paker, op.cit., p. 423.

38 Mesut Yllmaz was the leader of the Motherland Party (Anavatan Partisi-ANAP) between 1991-2002. 
Pandora's box and made an invitation to question the national security concept and its obscure definition ${ }^{39}$.

Consequently, it can be argued that in Turkey, the extended use of the national security concept contributed to the convergence of internal and external domains of security. Despite the criticisms directed against the use of the concept to include domestic security, beginning with the 1970s, the term was instrumentalized by military authorities to legitimize the role of the military to execute law enforcement functions inside state borders.

\section{National security and police-military relations in Turkey}

The modern state has its specialized institutions for providing security inside and outside state borders. Historically, with the establishment of the modern state, the legitimate use of coercive force has been distributed between two prominent institutions: the police and the military ${ }^{40}$. Ideally, the military defends the state against external enemies, whereas the police assure public order inside state borders. This separation between the police and the military created differences in the organization, doctrine, training, and tactics of these two coercive institutions ${ }^{41}$. Yet, until the beginning of the 20th century, this separation was not so clear. Instead, during this period, in many industrialized countries, the military was still being used to fight against protests and social incidents inside state borders ${ }^{42}$. The institutional and functional separation has become clear predominantly with the development of human rights, freedoms and the process of democratization. More significantly, with the rise of modern democracies in Europe, the distinction between the police and the military has become well-established and has appeared over time as the core values of the security sector in democratic countries ${ }^{43}$.

Despite the existence of an idealized distinction, countries worldwide have some legal and constitutional regulations enabling military forces to support or substitute for police forces ${ }^{44}$. In turn, the military has always performed police duties in Turkey and beyond. Yet, the changing scope and nature of the national security concept have impacted on this relationship between the police and the

39 Ü. Cizre, op.cit., p. 347.

40 M. Mann, The sources of social power. Volume 1: a history of power from the beginning to AD 1760, Cambridge - New York 1986, p. 11.

${ }^{41}$ A.D. Kincaid, op.cit., p. 41.

42 R.J. Goldstein, Political repression in modern America, from 1870 to the present, Cambridge 1978; C. Tilly, The contentious French, Cambridge 1986.

43 Security sector reform and democracy in transitional societies, eds. H. Born, M. Caparini, P. Fluri, Baden-Baden 2002.

44 A.D. Kincaid, op.cit., p. 41. 
military. It is argued here that the involvement of the military on the domestic sphere to execute police functions has become overwhelming with the broadening of the national security concept to include many issues related to security, without establishing any difference between internal and external domains of security. As Ü. Cizre puts it:

Military doctrine in Western democracies recognizes that national security is not an area that should be monopolized by military considerations. The best guarantee against the danger of military subordinating other national objectives to national security is the tradition in the West of maintaining a clear distinction between military and police roles, using the latter to respond to internal threats while restricting the role of the military to external defence ${ }^{45}$.

In Turkey, the TSK instrumentalized the national security concept as a legitimation mechanism for its involvement in domestic issues. Besides its direct military coups throughout the history of the Republic, the TSK acted as an internal security organization through the use of many mechanisms such as martial law practices and secret protocols.

From a historical perspective, in the 1970s, the main mechanism used by military authorities to have a word on domestic security issues was martial law practices. Interestingly, many civilian governments supported the establishment of martial law practices against the rising social disturbances and civil-war like situations. As Urhan and Çelik contended, the key instrument of the national security state was martial $\operatorname{law}^{46}$. Under the conditions dictated by the international bipolar system and the existence of ideological rivalries between two polars, with the military intervention of 1971, the military took side against left-wing social movements ${ }^{47}$. Since then, communism was conceived as a threat to national security $^{48}$. The examination of the MGK decisions of this period revealed that starting with the 190s, the MGK decisions were directed towards internal security concerns. In this regard, communism was conceived as the primary threat against the national security of Turkey ${ }^{49}$.

The emergence of the national security concept in the 1960s and its extended usage by military authorities enabled the military to become more active in the 1970s. In response to the incapacity of the police to overcome existing political

\footnotetext{
Ü. Cizre, op.cit., p. 218.

B. Urhan, S. Çelik, op.cit.

47 It can be argued that despite the 1960 military intervention being initiated against the Democrat Party government, the 1971 military intervention was against the rising social movements and politicization of masses.

48 B. Urhan, S. Çelik, op.cit.

49 İ. Akça, Yetmişli yıllarda hegemonya krizi, ordu ve militarizm, [in:] Türkiye’nin 1970'li yılları, ed. M. Kaan Kaynar, İstanbul 2020, p. 105.
} 
violence in the 1970s, the public security system became fragile. Here, the use of military forces in support or in place of the police became a common attitude. During this period, martial law practices were prevalent in many cities. Under a martial law regime, the police became subordinated to the military. The latter, in turn, assumed many new and previously police duties to execute law enforcement functions in the domestic sphere ${ }^{50}$.

In the 1980s, the military dominated the security sector for three years under the military regime following the 1980 coup d'Etat. Throughout this period, the military initiated a reform process under its own initiative for the professionalization of the police organization ${ }^{51}$. In the 1990s, with the consolidation of the national security state in Turkey, the military invented new mechanisms to execute police functions. The fusion of police-military relations became constant during this period, predominantly with the rise of Kurdish insurgency and reactionary Islam as two internal threats against the sake of the regime. These were perceived as threats to national security. An analysis of the official documents prepared by the MGK demonstrate that Kurdish separatism was perceived as the primary threat to national security in the first half of the 1990s while reactionary Islam replaced it to become the main enemy of the regime in the second half of the $1990 \mathrm{~s}^{52}$.

As a reaction against rising threats of political Islam and Kurdish separatism, the military, through the mechanism of the MGK initiated the so-called postmodern military coup in $1997^{53}$. The military, anxious about the rising threat of political Islam, perceived this as a concrete threat and initiated a military intervention with the support of the civil society ${ }^{54}$. As Cizre and Çinar ${ }^{55}$ argued:

(the military) took the accession of the WP (Welfare Party) into government as confirmation of its beliefs that Islamic reactionism, irtica in Turkish, had become a substantial threat to the secular character of the Republic.

Consequently, in 1997, the TSK self-proclaimed as the leader of the security sector. By doing that, it intervened to undertake po licing and law enforcement

50 N. Bölügiray, Sokaktaki asker: bir sıkıyönetim komutanının anıları, İstanbul 1989.

51 A. Genç Yllmaz, Competing roles of the police and the army: a historical analysis of the Turkish case, „Scandinavian Journal of Military Studies” 2020, vol. 3, no. 1, pp. 144-156.

52 National Security Policy Document was renewed and released after the 1997 postmodern military coup. The Document added political Islam as a new threat besides Kurdish separatism. See, Ü. Cizre, op.cit. and B. Oran, Türk dış politikası. 1. Cilt: 1919-1980: kurtuluş savaşından bugüne olgular, 1. Basım 24. Baskı, İstanbul 2020.

53 After forming a coalition government with TPP in 1995, the pro-Islamist Welfare Party (Refah Partisi, RP) rose to the power in 1996.

54 Ö. Aslan, op.cit., pp. 360-377.

55 Ü. Cizre, M. Çınar, Turkey 2002: kemalism, islamism, and politics in the light of the February 28 process, „The South Atlantic Quarterly” 2003, vol. 102, no. 2/3, pp. 309-332. 
roles. Significantly, under the military tutelage regime, the military was assigned to policing roles with the signature of the secret EMASYA Protocol. In Western democracies, intelligence operations are generally carried out by civilian authorities. On the contrary, in Turkey, intelligence activities were mainly performed by military authorities ${ }^{56}$. For example, the EMASYA Protocol enabled military authorities to gather all the necessary information and intelligence to fight against internal threats such as reactionary Islam and Kurdish separatism ${ }^{57}$. Additionally, the Protocol gave the military an extensive power and authority to act against internal threats without asking permission from civilian authorities ${ }^{58}$.

In 2000, The Defense White Paper which was released by the TSK mentioned Kurdish and religious terrorism as primary threats for the survival of the regime in Turkey ${ }^{59}$. Towards the end of 1999, the military aspect of the fight against the PKK terrorist organization has almost been concluded with success as the leader of the PKK, Abdullah Öcalan, was captured and imprisoned. Interestingly, with the establishment of the AKP government after the national elections of 2001, a civilianization process was initiated which would redesign the relationship between the police and military in a significant way. Despite the fact that civilian authorities became the primary actors in determining national security policies of the regime during this period, the national security concept preserved its extended definition.

\section{Civilianization process, the national security concept, and police-military relations in Turkey}

During the Helsinki Summit in 1999, Turkey was accepted as a candidate country to become a full member of the European Union (EU). In the context of European

56 Ü. Cizre, op.cit., p. 218.

57 A. Güney, Europeanization of civil-military relations in Turkey: civilianization without democratization, [in:] The europeanization of Turkey: polity and politics, eds. A. Tekin, A. Güney, London 2015, p. 118.

58 Turkish legislation had previously regulated the military's law enforcement functions through Article 11D and 11J of the Special Provincial Administration Law 5444. According to this law, the Gendarmerie General Commands and the Police Organization, under jurisdiction of the Ministry of Internal Affairs, are used as a police force for securing public order. When these forces fall short of assuring internal order, the local governors may request aid from the military forces. Yet, the EMASYA Protocol bypassed the Special Provincial Administration Law no. 5442. See, L. Sarribrahimoğlu, Jandarma Genel Komutanliğl, [in:] Almanak Türkiye 2005 güvenlik sektörü ve demokratik gözetim, ed. Ü. Cizre, İstanbul 2005.

59 White Paper-Defense 2000 [1 VIII 2000], https://www.files.ethz.ch/isn/154907/Turkey _2000eng.pdf (31 VIII 2021). 
conditionality, the governments in power ${ }^{60}$ initiated many reforms in the name of democratization as the EU asks of candidates to be a democratic state respectful of human rights and have a working market economy ${ }^{61}$. The security sector reform (SSR) was the main component of this reform process as the establishment of civilian control of the military is particularly important to meet the democratic conditionality of the $\mathrm{EU}^{62}$. During the membership process of Turkey, the EU's criticisms targeted the primary institutional mechanism of military tutelage, the MGK, as it influenced the political process and acted like a parallel government ${ }^{63}$. Within this context, political authorities initiated a rapid reform process and established numerous legal and constitutional regulations. In the first place, the MGK Law was amended to curtail the military's power. According to the amended Law, the number of civilian authorities in the MGK increased and the power of the MGK's decisions have become limited to simple recommendations for the Council of Ministers ${ }^{64}$. In July 2003, an amendment was realized in Law on the MGK no. 2945. Since then, the MGK's power has become limited to making advisory decisions on issues pertaining to determination, establishment and implementation of the national security policy ${ }^{65}$.

The civilianization process put an end to the military tutelage regime. This, in turn, reshaped police-military relations which were previously dominated by the military. In 2010, the EMASYA Protocol was abolished, and this amendment curtailed the power of the military in internal security. One year later, a symbolic change took place, and police forces instead of the military ones became responsible for providing security and public order at the entrance of the TBMM ${ }^{66}$. Finally in 2016, following a failed coup attempt, gendarmerie forces were separated from military control. Now, they are placed under the jurisdiction of the Interior Ministry.

With the transformation of the nature and content of the MGK and its power, civilian authorities became the primary actors in determining national security policies of the regime. Yet, the changing nature of the MGK and institutional reforms has not brought with it radical changes in the definition of the national

60 The EU-oriented reforms were initiated by the Three Party Coalition Government (1999-2002). The coalition was formed by the Motherland Party, Later, the single party regime of the JDP under the leadership of Recep Tayyip Erdoğan continued the reform process.

61 European Neighbourhood Policy and Enlargement Negotiations, https://ec.europa.eu/neighbourhood-enlargement/policy/glossary/terms/accession-criteria_en (31 VIII 2021).

62 I. Turan, Y. Gürsoy, The role of the EU in changing the role of the military, „European Review of International Studies" 2014, vol. 1, no. 1, p. 133.

63 Ibidem, p. 136.

64 Ü. Cizre, op.cit., p. 222.

65 A. Kars Kaynar, op.cit.

66 Law no. 6253, Article 40, Official Journal no. 28146, 18 XII 2011, https://www.resmigazete. gov.tr/eskiler/2011/12/20111218-1.htm. 
security concept. Despite the changes realized under the civilianization process, a clear-cut separation between public security and national security could not be put into practice as a consequence of the extended definition of the national security concept which remained almost the same during the same period. Yet, this time, following the subordination of the military to civilian control, the police have become a significant player who holds the necessary initiative to benefit from the extended national security concept. Significantly, in 2016, through a Decree Law enacted on 25 VII, the police got the initiative to use the weapons of Gendarmerie and Coast Guard Command in case a national security issue occurs ${ }^{67}$.

Very recently, a law called Turkish Armed Forces, National Intelligence Agency and General Directorate of Security Movable Property Regulation (Türk Silahlı Kuvvetleri, Milli İstihbarat Teşkilatı and Emniyet Genel Müdürlüğü Taşınır Mal Yönetmeliği) was enacted on 5 I 2021 through a Presidential Decree. According to the enacted law, in case of terrorist and social incidents, the TSK's weapons, vehicles, and other technical staff can be transferred to the Police Organization. To put differently, with the publication of the enacted law, now, that the police have the opportunity to reach the necessary high weapons which were previously appropriated to the military. In fact, under ordinary conditions, the use of coercive force by the police is regulated by Article 16 of the Polis Vazife ve Salahiyet

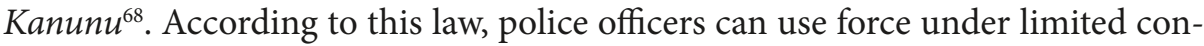
ditions and in a proportional way. The recently enacted law reshapes the use of coercive force by the police through the extension of the conditions and elimination of the principle of proportionality. It regulates the necessary conditions permitting these security institutions to exchange their weapons and vehicles based on a very broad definition of national security concept. According to Article 21 of the same law, in case of terrorism, social incidents, and violent acts threatening national security, public order and public security, civilian public authorities can permit the exchange of the necessary equipment between security institutions.

In conclusion, it can be contended that with the end of the military tutelage regime in Turkey, the police-military fusion took a new turn. The military has been placed under civilian control and ensured to act as an institution responsible for the fight against external threats. On the other hand, the police have become the main actor in internal security in search of increasing its power and getting militarized through the vast and extended definition of the national security concept.

67 During the 1997 postmodern coup, the high tech weapons of the police had been taken from them. With the enacted decree law, this situation was reversed. The law was enacted just after the 15 VII attempted coup d'Etat.

68 Law no. 2559, Official Journal no. 2751, 14 VII 1934, https://www.mevzuat.gov.tr/MevzuatMetin/2.3.28501.pdf. 


\section{Conclusion}

The national security concept has always had a significant place in Turkish legislation and Turkish politics. From the 1960 coup d'Etat, when it was used for the first time from a legal and constitutional perspective, until today the concept preserves its importance. This paper contends that the extended use of the national security concept is significant for Turkish politics as it redesigned the role distribution among security institutions in the country.

From a historical perspective, the national security concept emerged as a military technical-strategic term employed by military authorities and since then, the TSK has instrumentalized the national security concept to be involved in domestic politics. While doing that, the military aimed to extend its scope of authority in such a way to execute law enforcement functions and missions. In this context, military and police functions started to converge in favor of military authorities. Based on the national security concept, the military tutelage regime was established to govern the country for decades. During this period, in the name of defending national security, the military acted like the sole actor in the security sector. The military dominated security regime survived until the civilianization process of the 2000s. The absorption of policing roles in military apparatus became significant throughout the 1990s when rising internal threats of political Islam and Kurdish separatism were perceived as threatening the survival of the regime. During this same time period, in Turkey, a national security state was consolidated.

Despite the existence of considerable progress in demilitarization of the security sector and of many criticisms directed against the vague and extended definition of the national security concept throughout the 2000s, interestingly, the national security concept keeps its significance. Put differently, with the establishment of civilian control of the military, various dimensions of the country's security are discussed now under the civilian dominated MGK. Subsequently, police-military relations in the country have been affected by the dissolution of the military actors as primary security actors and the current survival of the national security concept. This time, the police as an actor, holds the potential power to use the extended national security concept so that it would increase its role in the security sector. In other words, police-military relations in the country seem to be redesigned in favor of the police with the help of the still dominant national security concept.

As the recent legal regulations, such as the law enacted in 2021, Turkish Armed Forces, National Intelligence Agency and General Directorate of Security Movable Property Regulation, demonstrates, currently in Turkey, the notion of "public order" is still absorbed by that of „national security." The convergence of national and public security enables now that the police can use some sort of 
militarized weapons which were previously held by the military. It seems nearly obvious that in the near future, this law may have considerable impacts on the relationship between the police and military. This time, the convergence between the police and the military may be established in favor of the police as it has militarized and powerful equipment, vehicles, and weapons that can be used in case of social incidents and terrorist attacks classified as issues related to a country's national security.

In short, despite the abolishment of the military tutelage regime starting with the 2000s, the vast and imprecise use of the national security concept has almost remained the same. Previously, before the civilianization process, the national security priorities of the country were predominantly decided and determined by the military authorities. Based on this, the military self-declared as the head of the security sector and acted instead or in support of the police whenever it wanted to do so. Thus, the absorption of public security by national security long served as a mechanism for the military to lead the security sector in the country. Here, the convergence of police and military roles took place in favor of military authorities as the national security concept was defined and interpreted predominantly by them. Yet, after the civilianization process, this time, the police started to search for new opportunities to increase its sphere of influence by using an all-encompassing national security concept. Or the coup-proofing strategies of political authorities enabled the police to benefit from the never-changing national security concept and the reorganization of roles between the police and the military.

\section{Abstract}

Ayfer Genç Yılmaz

\section{The national security concept and police-military relations in Turkey}

The broad definition of the national security concept has always been a highly contested subject in Turkey. Yet, the existing studies have not addressed much-needed focus on the relationship between this obscure definition of the concept and its impact on police-military relations. To fill this gap, this paper analyzes police-military relations in Turkey in light of the historical development of the national security concept. In this regard, in this paper it is argued that the imprecise and all-encompassing use of national security concept remains unchanged in the aftermath of the civilianization process of the 2000s. As the national security concept continues to maintain its extended meaning, 
the convergence of police-military roles persists but gets to be reformulated. Yet, under these circumstances, the police appear to be like the great beneficiary of this convergence of roles as the military tutelage regime came to an end and the civilian control of the military has been fully established.

Keywords: national security, military, police, Turkey, convergence

\section{References}

Akça, İ., Yetmişli yıllarda hegemonya krizi, ordu ve militarizm, [in:] Türkiye’nin 1970'li yılları, ed. M. Kaan Kaynar, İstanbul 2020.

Aslan, Ö., Unarmed' we intervene, unnoticed we remain: the deviant case of 'February 28th Coup' in Turkey, „British Journal of Middle Eastern Studies” 2016, vol. 43, no. 3 .

Bölügiray, N., Sokaktaki asker: bir sıkıyönetim komutanının anıları, İstanbul 1989.

Cizre, Ü., Demythologizing the national security concept: the case of Turkey, „Middle East Journal" 2003, vol. 57, no. 2.

Cizre, Ü., Çınar, M., Turkey 2002: kemalism, islamism, and politics in the light of the February 28 process, „The South Atlantic Quarterly” 2003, vol. 102, no. 2/3.

Çelik, S., Osmanlidan günümüze devlet ve asker, askeri bürokrasinin sistem içindeki yeri, İstanbul 2007.

Demirel, T., 12 eylüle doğru ordu ve demokrasi, „Ankara SBF Üniversitesi Dergisi” 2001, vol. 56, no. 4.

Dimitrijevic, B., The concept of security in international relations, Beograd 1973.

Erdal, M., National security in the constitution, [in:] Bir zümre bir parti Türkiyede ordu, 1st Edition, eds. A. Bayramoğlu, A. İnsel, İstanbul 2004.

Ergut, F., Modern devlet ve polis, Osmanlidan Cumhuriyet'e toplumsal denetimin diyalektiği, İstanbul 2004.

European Neighbourhood Policy and Enlargement Negotiations, https://ec.europa.eu/neighbourhood-enlargement/policy/glossary/terms/accession-criteria_en.

Genç Yllmaz, A., Competing roles of the police and the army: a historical analysis of the Turkish case, „Scandinavian Journal of Military Studies” 2020, vol. 3, no. 1.

Goldstein, R.J., Political repression in modern America, from 1870 to the present, Cambridge 1978.

Güney, A., Europeanization of civil-military relations in Turkey: civilianization without democratization, [in:] The europeanization of Turkey: polity and politics, eds. A. Tekin, A. Güney, London 2015. 
Gürpınar, B., Milli Güvenlik Kurulu ve dış politika, „Uluslararası İlişkiler” 2003, vol. 10 , no. 39 .

Karaosmanoğlu, A.L., The evolution of the national security culture and the military in Turkey, „Journal of International Affairs” 2000, vol. 54, no. 1.

Kars Kaynar, A., Political activism of the National Security Council after the reforms, „Armed Forces\&Society” 2017, vol. 43, no. 3.

Kincaid, A.D., Demilitarization and security in El Salvador and Guatemala: convergences of success and crisis, „Journal of InterAmerican Studies and World Affairs" 2000, vol. 42, no. 4.

Law no. 2945 on the MGK and the secretariat-general of the MGK published in Official Journal, no. 18218, 11 XI 1983.

Law no. 6253, Article 40, Official Journal no. 28146, 18 XII 2011, https://www. resmigazete.gov.tr/eskiler/2011/12/20111218-1.htm.

Law no. 2559, Official Journal no. 2751, 14 VII 1934, https://www.mevzuat.gov.tr/ MevzuatMetin/2.3.28501.pdf.

Mann, M., The sources of social power. Volume 1: a history of power from the beginning to AD 1760, Cambridge, New York 1986.

Milli Güvenlik Konseyince kabul edilen kanunlar, yayınlanan bildiri ve kararlar ile önemli mevzuat, ed. İ. Gülsün, C. 8., Ankara 1984.

Oran, B., Türk dış politikası. 1. Cilt: 1919-1980: kurtuluş savaşından bugüne olgular, 1. Basım 24. Bask1, İstanbul 2020.

Özcan, G., Türkiye'de milli güvenlik kavramının gelişimi, [in:] Türkiye'de ordu, devlet ve güvenlik siyaseti, eds. İ. Akça, E. Balta Paker, İstanbul 2010.

Pion-Berlin, D., Latin American national security doctrines: hard and softline themes, „Armed Forces\&Society” 1989, vol. 15, no. 3.

Pion Berlin, D., The Military and Internal Security Operations in Latin America, „Revista Politica y Estrategia” 2017, vol. 130.

Resteigne, D., Manigart, P., Boots on the streets: a policization of the armed forces as the new normal?, „Journal of Military Studies" 2019, vol. 8, no. 1.

Sarlak, Z.A., History of the National Security State in Turkey, The Doctoral Dissertation, University of Leiden, August 2020.

Sarribrahimoğlu, L., Jandarma Genel Komutanlı̆̆ı, [in:] Almanak Türkiye 2005 güvenlik sektörü ve demokratik gözetim, ed. Ü. Cizre, İstanbul 2005.

Security sector reform and democracy in transitional societies, eds. H. Born, M. Caparini, P. Fluri, Baden-Baden 2002.

Sorensen, T.C., Rethinking national security, „Foreign Affairs” 1990, vol. 69, no. 3. Stepan, A., The new professionalism of internal warfare and military role expansion, [in:] Authoritarian Brazil origins, policies, and future, ed. A. Stepan, New Haven 1973.

Tilly, C., The contentious French, Cambridge 1986. 
Turan, I., Gürsoy, Y., The role of the EU in changing the role of the military, „European Review of International Studies" 2014, vol. 1, no. 1.

Urhan, B., Çelik, S., Perceptions of national security in Turkey and their impacts on the labour movement and trade union activities, „European Journal of Turkish Studies" 2010, vol. 11, https/doi,org/10.4000/ejts.4333.

Ülman, B., Doksanlarda Türkiye’nin yeni güvenlik algılamaları ve 'bölücülük' [in:] En Uzun Onyll: Türkiye’nin ulusal güvenlik ve dış politika gündeminde doksanl yillar, 1st Edition, eds. G. Özcan, Ş. Kut, İstanbul 1998.

Weiss, T., The Blurring Border Between the Police and the Military: A Debate Without Foundations, „Cooperation and Conflict” 2011, vol. 46, no. 3.

White Paper-Defense 2000 [1 VIII 2000], https://www.files.ethz.ch/isn/154907/ Turkey_2000eng.pdf.

Wolfers, A., National Security as an ambiguous symbol, „Political Science Quarterly" 1952, vol. 67 , no. 4 .

Ayfer Genç Yllmaz - adiunkt w zakresie nauk politycznych w Istanbul Commerce University. ORCID: 0000-0002-4714-0639 